This is the Accepted Version of an article published online by Sage in Politics

Please refer to final version when citing, published online 1 May 2016 available at:

$\underline{10.1177 / 0263395716628886}$

Accepted Version downloaded from SOAS Research Online: http://eprints.soas.ac.uk/22523/

\title{
Teaching Africa and International Studies: forum introduction ${ }^{1}$
}

\author{
Julia Gallagher, Carl Death, Meera Sabaratnam, Karen Smith²
}

\footnotetext{
${ }^{1}$ This forum was born out of a set of workshops on 'Teaching Africa and International Studies', funded by the UK's Higher Education Academy, the British International Studies Association Working Group for Africa and International Studies, and our home institutions - the University of Cambridge, Royal Holloway University of London, and the University of Cape Town. We are very grateful for the support of all these institutions. We are even more indebted to the many participants and paper-givers from several continents who attended, physically and virtually, offering up their thoughts, questions and experiences of teaching 'Africa' in international studies. 2 Julia Gallagher, Department of Politics and International Relations, Royal Holloway, University of London, Julia.gallagher@rhul.ac.uk Carl Death, School of Social Sciences, University of Manchester Carl.death@manchester.ac.uk Meera Sabaratnam, Department of International Politics, School of Oriental and African Studies, Ms140@soas.ac.uk Karen Smith, Department of Political Studies, University of Cape Town, Karen.smith@uct.ac.za
} 
This is the Accepted Version of an article published online by Sage in Politics

Please refer to final version when citing, published online 1 May 2016 available at:

$\underline{10.1177 / 0263395716628886}$

Accepted Version downloaded from SOAS Research Online: http://eprints.soas.ac.uk/22523/

\title{
Key words: Africa; International Studies; Teaching
}

\begin{abstract}
Africa has often been defined and represented by outsiders. In International Studies, the continent is frequently viewed as peripheral and uninteresting. This is clearly a problem, and an increasingly apparent one as the number of courses on Africa and IS grow, both in Africa and beyond. Many academics who run these courses are keen to challenge the continent's traditional marginalisation and perceived dependency, but they are limited by the resources available to them, and the fact that many are establishing new courses from scratch. This article outlines some of the key debates around teaching Africa and IS, setting the scene for the articles that follow.
\end{abstract}


This is the Accepted Version of an article published online by Sage in Politics

Please refer to final version when citing, published online 1 May 2016 available at:

$\underline{10.1177 / 0263395716628886}$

Accepted Version downloaded from SOAS Research Online: http://eprints.soas.ac.uk/22523/

\section{Teaching Africa and IS: forum introduction}

This forum is motivated by two related questions. The first is how should we teach 'Africa' in International Studies? And the second is how should we teach 'International Studies' in Africa? ${ }^{3}$ Although these questions appear to come from opposite directions, the challenges that underwrite them have much in common - these are explored, compared and developed in the five articles that follow.

Our starting point is one which acknowledges and engages the traditions of 'critical pedagogy' (Freire 2005, Giroux 1988; hooks 1994) - that is, the idea that education should not only teach 'critical thinking' but should in some sense advance projects of social justice, transformation and empowerment (KeesingStyles 2003). Freire's critique of the 'banking model' of education remains pertinent: students are not empty receptacles to be filled with facts, but rather '[k]nowledge emerges only through invention and re-invention, through the restless, impatient, continuing, hopeful inquiry human beings pursue in the world, with the world, and with each other' (Freire 2005: 72). Diverse literatures emphasise the idea that that the curriculum is a political text and that teaching is itself a kind of political intervention, involving the reinforcement, contestation or transformation of the relationship between the student and the world around them (Müller 2011). We tend to agree with bell hooks, that the classroom remains the most radical space of possibility in the academy' (1994: 12). As such, our context for teaching about 'Africa' is one in which the relations between regions and peoples at a global level are steeped in legacies of global exploitation, dispossession and marginalisation, even as they are rapidly transforming (Lonsdale 2005; Mama 2007).

Many of us who teach in the UK have learnt from core courses in International Studies (IS) that have treated Africa as an intellectual leftover, dealt with by

\footnotetext{
3 The overarching title of the forum is International Studies (IS) because it includes teaching in the fields of international history and comparative politics as well as international relations.
} 
This is the Accepted Version of an article published online by Sage in Politics

Please refer to final version when citing, published online 1 May 2016 available at:

$\underline{10.1177 / 0263395716628886}$

Accepted Version downloaded from SOAS Research Online: http://eprints.soas.ac.uk/22523/

major approaches as an example of the failure or absence of 'proper' international relations (see Jackson 1993). Such syllabi have reflected a historic disinterest in, or ignorance of, African inter-state and inter-polity relations amongst the most prominent scholars in the discipline of International Relations. Emblematic of this tendency is Kenneth Waltz's recent admission that he chose to ignore Africa in his writings deliberately, and as a result it has constituted a 'blank spot' for him. He nonetheless goes on to speculate about the 'primitive' nature of African society as inhibiting inter-state warfare (Theory Talks 2011). Another classic text, Bull and Watson's Expansion of International Society (1984) contains the bold judgement by Bull that 'there was no African international system or international society' prior to European colonisation in the nineteenth century (quoted in Pella 2014: 16) - a claim contested by Pella (2014).

This vacuum has been frustrating on multiple fronts - intellectually, because it reinforces lazy and often factually incorrect stereotypes about the continent, as well as the legitimacy of mainstream academic discourses to make generic pronouncements on it, and pedagogically because it encourages our students to switch off their critical faculties when presented with such accounts. Such tendencies are more broadly consonant with the place of 'Africa' as a (mis)represented object in Western academic discourse (Mudimbe 1990). The establishment of a geoculturally 'Western' Self depends, as Said (2003 [1978]) reminds us, on the establishment of its barbarous or backwards Other. Seen in the light of critical pedagogical literature which emphasises the role of educational curricula in reproducing problematic discourses, the relation between the pedagogical and the geopolitical are mutually reinforcing (Müller 2011). As Giroux notes for education more generally, 'questions concerning the role of the school as an agency of social and cultural reproduction in a classdivided society are ignored' (1988: 6). The same might be said for teaching International Studies in universities: it is vital to remain attuned to the possibility for classrooms to be sites of domination and hegemony, as well as spaces of critical and engaged global citizenship (Freire 2005; hooks 1994). 
This is the Accepted Version of an article published online by Sage in Politics

Please refer to final version when citing, published online 1 May 2016 available at:

$\underline{10.1177 / 0263395716628886}$

Accepted Version downloaded from SOAS Research Online: http://eprints.soas.ac.uk/22523/

Option courses do present opportunities to deepen and broaden students' understanding of African domestic and international politics; however, we are often frustrated by working with sometimes limiting literatures and students' own expectations that they would be primarily dealing with problems of conflict, humanitarian crisis and poverty. These expectations are reinforced by major IR textbooks, such as Baylis, Smith and Owens' The Globalization of World Politics, which emphasise these as primary issues for the continent. ${ }^{4}$ Many students take these option courses because they hope to work for relief or development organisations in the future, and so they are implicitly invested in the continuing equivalence of Africa and disaster or development.

The second question - how do we teach IS in Africa - emerges as many African universities are growing in size, number and quality, with an increasing demand from students to study IS, and International Relations (IR) in particular (Lonsdale 2005; Mama 2007). But what kind of syllabus, and what kind of resources, would meet these demands? What is the impact of teaching a historically Eurocentric canon? Is there a potential for re-making the discipline itself as its homes multiply? Or do students demand standardisation to a dominant mainstream as a means of internationalising their own education?

Posing these questions together generates productive tensions, and even discomforts, about the purposes of higher education (Giroux 1988). To what extent do academics working in UK and African universities share common challenges, and to what extent do our different political and institutional settings define these differences? The five papers in this forum address these questions from the perspectives of African and European academics, all of whom are engaged in teaching courses on Africa in IS. Between them they explore big questions about the marginalisation of Africa in world politics and in IS literatures, the sometimes troubling expectations of students who take courses on Africa, and they discuss innovative and imaginative ways of tackling some of these problems through what and how they teach.

\footnotetext{
${ }^{4}$ A scan through the index immediately demonstrates this approach (Baylis et al 2013: 571)
} 
This is the Accepted Version of an article published online by Sage in Politics

Please refer to final version when citing, published online 1 May 2016 available at:

$\underline{10.1177 / 0263395716628886}$

Accepted Version downloaded from SOAS Research Online: http://eprints.soas.ac.uk/22523/

Some of the themes explored are particular to the study of Africa. Few other regions of the world are presented as alien, exotic, marginal and 'different' to the same degree, for example (Cornelissen et al 2011). Moreover, as the poorest or 'least developed' continent in the world according to mainstream assumptions about modernist development, education and the university sector in Africa face particular challenges which it is impossible to ignore as professionals, working within a sector committed to positive social change (Death et al 2015; Lonsdale 2005; Mama 2007). Reflecting on the implications of these issues for how we 'teach Africa and IS' raises questions not just for scholars of African politics, but also for how IS represents what is 'normal', and how new ways of thinking about African politics can challenge and enrich the field, both in how it is viewed and in how it is included in broader university curricula.

Other themes are more generalizable. These speak to the place of 'area studies' in courses on politics and IS and the diversity of our curricula, and ways of challenging students who have adopted superficial ideas about the wider world, by using imaginative teaching techniques (hooks 1994).

We use this introduction to frame some of the key themes and debates that are developed in the papers that follow. In the first section, we discuss the challenges of teaching a continent that is seen as marginal in world politics. In the following sections we explore two approaches to tackling these problems: prioritising African voices; and creativity in teaching Africa. These approaches will not all be to everyone's taste, and they throw up further awkward questions. In writing about them, our ambition is to provoke thought and discussion rather than to insist on a specific way forward. Nonetheless, we collectively argue that better pedagogies cannot be fully achieved by teachers alone, but require a dialogue with students, institutions, disciplinary collectives and the political economy of higher education itself. 
This is the Accepted Version of an article published online by Sage in Politics

Please refer to final version when citing, published online 1 May 2016 available at:

$\underline{10.1177 / 0263395716628886}$

Accepted Version downloaded from SOAS Research Online: http://eprints.soas.ac.uk/22523/

\section{Africa: alien and peripheral?}

One of the things about Africa that often draws European students to study it is its 'exoticism', as represented in popular culture (Dunn 1996; Harrison 2013; Lonsdale 2005). Students may be fascinated by the thought of studying conflicts that they have been told involve children, diamonds, drugs or witchcraft (Evans et al 2010; Martins 2011). They may imagine that political problems in Africa occur on a particularly grand scale and they want to learn about the genocide in Rwanda, or piracy and state collapse in Somalia, or global cyber-scams and corruption in Nigeria. Others may choose courses on Africa because they are driven by humanitarian concerns. In UK schools children are taught from an early age to view Africa as a helpless place of famine and disease, through projects such as Comic Relief (Gallagher 2011). Television charity extravaganzas hammer home the pitiable state of Africa and glamourise the Western pop-stars and celebrities who go there to help (Nash 2008). It is this narrow approach that has led Nigerian author Chimamanda Ngozi Adichie to lament what she calls the "danger of the single story about Africa", particularly as it is a "single story of catastrophe" (2013). As a result many students tend to have a one-sided view of Africa as irreducibly linked to development crisis, somewhere that needs outsiders to sort it out.

These assumptions are rooted in particular fantasies about Africa as a continent, and its relationship with the West, that have a long, problematic history, tied to the slave trade and its abolition, and to colonialism, and reinforced by a theoretical tradition that is rooted in particular ideas of progress and modernity (Gallagher, 2011; Harrison, 2013; Shilliam 2011). In many ways ideas of who 'we' in the West are have been constructed in relief to 'them' in Africa. Without being aware of it, many students carry with them the baggage of wider European culture and attitudes towards Africa, and it can be the case that large amounts of classroom time are spent addressing and challenging this. Some of us have viewed part of our job in teaching Africa as one in which we prise students away from assumptions about what 'civilisation' looks like, or from dearly cherished 
This is the Accepted Version of an article published online by Sage in Politics

Please refer to final version when citing, published online 1 May 2016 available at:

$\underline{10.1177 / 0263395716628886}$

Accepted Version downloaded from SOAS Research Online: http://eprints.soas.ac.uk/22523/

hopes that they can find a way to 'fix' the continent. Letting go of long-held career ambitions - or at least realising that your potential role is limited and problematic - can create strong emotional reactions (hooks 1994: 18). The articles by Routley, Gibert, and Ambrozy and Harris all address these problems.

Evidence of how deep-seated this problem is can be is seen in some African universities where Africa's marginalisation or exoticism is also propagated (Lonsdale 2005; Mama 2007). In her article, Matthews discusses the problems she has faced in teaching Africa to South African students, many of whom begin her course with highly problematic assumptions about the (rest of the) continent as impoverished, diseased and war-torn. Such assumptions are not helped when much of the literature available is written by Western academics - even where these are thoughtful and sensitive, their domination of syllabi prolongs the notion that Africans have little to contribute. This problem opens up questions about finding and using African authors and perspectives that are addressed throughout the forum.

In African universities the question of African 'difference' can take a further problematic turn. Here, many academics feel a sense of responsibility to redress a Western-oriented discipline and literature by providing African challenges and perspectives (and there are now some texts that attempt to do this - see Brown and Harman 2013; Cornelissen et al 2012; Dunn and Shaw 2001; Shilliam 2011). Sometimes this is in response to renewed demands by students for an 'Africanised' curriculum. For example, the 'Rhodes Must Fall' movement that started at the University of Cape Town in 2015 - initially questioning the continued presence of a statue of British colonialist Cecil John Rhodes on the campus - has reignited discussions about transformation of higher education in South Africa. Together with the transformation of the staff profile, the Africanisation or de-Westernisation of the curriculum has been a central point of contention. At the same time, in attempting to redress this imbalance, many lecturers have met with hostility from students who want to do 'proper IR'. Some feel that a 'parochial, African' perspective will merely exclude them from the key 
This is the Accepted Version of an article published online by Sage in Politics

Please refer to final version when citing, published online 1 May 2016 available at:

$\underline{10.1177 / 0263395716628886}$

Accepted Version downloaded from SOAS Research Online: http://eprints.soas.ac.uk/22523/

discussions that shape international politics, and from becoming conversant with the issues that will eventually get them jobs. So negotiating the historical tendency in IR to dismiss the 'periphery', and combatting the dearth of literature that includes African players and perspectives remains problematic. Within this context, Niang's article is a provocative call to re-frame the study of IS within African paradigms - and to reshape international politics from discipline to practice.

In discussions about how to approach teaching Africa and IR, three key debates emerge. First, should we prioritise or at least give a heavier weighting to African authors in our teaching? If so, how? Second, how far can we use creativity - using unconventional texts and sources, for example - in our teaching? What implications might there be for perceptions of Africa as 'lightweight' compared to more 'serious' or 'important' parts of the world if we do so? And third, to what degree should we demand that students become more introspective and selfcritical when approaching the study of Africa? Is such an approach self-indulgent, or a key way to nourish thoughtful and self-aware graduates? These debates are explored in the following sections.

\section{Should we prioritise African voices?}

African students are often confronted with textbooks and other readings that only mention the continent in which they live in passing. The issues and concerns they raise, the case studies which they draw upon, and the outlook and assumptions they reflect, are usually those of Europe and America - the places where they are produced. African political concerns are simply not considered (Nossal, 2001). One might assume that there is no international politics in Africa, and that Africans have nothing to contribute to its study. 
This is the Accepted Version of an article published online by Sage in Politics

Please refer to final version when citing, published online 1 May 2016 available at:

$\underline{10.1177 / 0263395716628886}$

Accepted Version downloaded from SOAS Research Online: http://eprints.soas.ac.uk/22523/

We are all concerned that African Studies and IR in Africa be taught in a way that presents Africa not as an object but rather as an agent. ${ }^{5}$ Drawing on readings that highlight Africa's active engagement in the international system, through multilateralism and African contributions to the fields of conflict resolution, helps challenge entrenched notions of Africa as a passive object that is forever acted upon (Fanon 1986; Mudimbe 1990).

For these reasons, it is essential that students are exposed to African voices writing about IR - voices that might see the world from a different perspective and help them to challenge mainstream assumptions. ${ }^{6}$ As Matthews' article explains, this is often done by juxtaposing non-Western texts with the standard literature, using the former to criticise the latter.

However, there are potential dangers with prioritising African authors. One is that texts do not always present innovative or alternative views just because they have been written by Africans. Many African scholars write in a way that is not very different from their Western counterparts - drawing on the same theoretical assumptions, focusing on the same issues (Fanon 1986; Freire 2005). There are a number of reasons for this, including what some have referred to as the postcolonial affliction of mimicry (in an attempt to be regarded as equals), and academic pressures that push scholars into publishing in internationally accredited journals which tend to be conservative and restrictive of alternative perspectives (Aydinli and Matthews, 2000). Alternatively, it is possible to overdo 'difference': Africans don't always view things differently, and it is important to recognise similarity, rather than continually looking for disrupting narratives in Africa (Bilgin, 2008).

A second issue is that of authority: some of us find - both in Africa and in Europe - that our students tend to idealise African authors, seeing them as providing

\footnotetext{
5 Brown and Harman's (2013) book provides some material in this regard.

${ }^{6}$ A good example is Cheru, Cornelissen and Shaw's book (2012) which includes African case studies that challenge assumptions about the way states behave in IR.
} 
This is the Accepted Version of an article published online by Sage in Politics

Please refer to final version when citing, published online 1 May 2016 available at:

$\underline{10.1177 / 0263395716628886}$

Accepted Version downloaded from SOAS Research Online: http://eprints.soas.ac.uk/22523/

'authentic' understandings, while Western authors are inherently suspect. This problem will persist until a better representation of African authors on reading lists has normalised their place there.

Third is the problem of parochialism: do we run the risk, particularly with courses on IS in Africa, of turning from a Western-focused study to an Africanobsessed one? Here it is important to recognise that it is not only African experiences that have been silenced, but also the experiences of much of the developing world, as well as many marginalised voices within the West. To avoid parochialism, students should also be introduced to the histories and experiences of Asia and South America. Expanding our archive in many directions - particularly in light of the rise of the emerging powers like China, India and Brazil - to include knowledge and understanding of many parts of the world that have been marginalised in IR, can help challenge a discipline that has been built on excluding the experiences and contributions of the majority of the world (Shilliam 2011).

Alongside all these difficulties is a practical one: there is a relative shortage of African academic sources on international politics. To tackle this, many of us turn to non-academic sources and alternative histories. African and other 'alternative' contributions to IR, for example, will not always clearly be identifiable as 'IR' texts. Novels, for example, provide a rich source of thinking about issues related to IR from African perspectives. Relatedly, in light of the fact that IR is based on an implicitly Western-centred history of the world, it is important to introduce students to alternative histories, such as the international relations of the Ashanti kingdom (see Ayers 2006).

Within pedagogy and research, however, it may not be enough to simply draw on creative texts as a potential archive of African political and aesthetic values. These are valuable and important, but do not themselves help overcome the idea of an intellectual division of labour between the West and Africa in which the former produces 'proper' intellectual texts, and the latter produces 'art'. Rather, 
This is the Accepted Version of an article published online by Sage in Politics

Please refer to final version when citing, published online 1 May 2016 available at:

$\underline{10.1177 / 0263395716628886}$

Accepted Version downloaded from SOAS Research Online: http://eprints.soas.ac.uk/22523/

engaging with the international politics of Africa also requires engaging with African political thought and thinkers in diverse forms (e.g. Fanon 1986; Mama 2007; Martin 2012; Mudimbe 1990).

There are several compelling reasons for doing so. At the structural level, it is important to make the key point that Africans in fact have political thought, ideologies, intellectual disagreements about the ways in which society should be ordered, just as elsewhere in the world. Without such an appreciation, we develop a highly reductive explanatory account of political behaviour in Africa driven only by material gains, manipulated advantages, kinship-based loyalties and so forth (see Clapham 1996; Lonsdale 2005). This hyper-rationalist account of behaviour discursively strips Africans of their capacities for political action, emancipatory or otherwise - instead people are just understood as always effectively motivated by greed.

However, deciding what to teach as 'African political thought', and how, is beset by intellectual problems emanating from the specific position of various African polities within a (post)colonial matrix. ${ }^{7}$ The first problem is that this matrix presents scope for denying the very possibility of African political thought. Theory on Négritude by Senghor and Ujamaa by Nyerere, are sometimes presented as not 'really' African but 'Western', because they were framed by groups of privileged émigrés who had studied in colonial metropolitan centres and were not intended for African audiences (see also Fanon 1986). Debates around this position speak to the character of political 'authenticity', and open up questions about how far the international and heterodox origins of ideas disqualifies them from being properly 'African'. The unevenness in the conditions of producing African political thought in different times and places needs to be managed and negotiated when we are studying it.

\footnotetext{
7 These problems were confronted in the first workshop after a discussion of an African Political Thought reading group run by Meera Sabaratnam in Cambridge.
} 
This is the Accepted Version of an article published online by Sage in Politics

Please refer to final version when citing, published online 1 May 2016 available at:

$\underline{10.1177 / 0263395716628886}$

Accepted Version downloaded from SOAS Research Online: http://eprints.soas.ac.uk/22523/

The larger challenge posed by the (post)colonial matrix in which we study African political thought is that students and teachers from former colonial power centres can find it difficult to engage with thinking that has developed around questions that speak to and from grassroots politics. These do not necessarily fit within the areas laid down by the canon with which they are more familiar; and often the types of question they pose, and the ways in which they develop answers, do not fit conventional methodological approaches. For example, issues may include political beliefs and ideologies around identity, land possession and tenure, the place of religious authorities in society, the place of the family and the distribution of wealth. Many are not translated into English or French, and are not necessarily written down. Very little intellectual or professional value is placed within IS on developing a detailed understanding of these as political ideologies and systems of thought - rather they are exoticised as cultural artefacts to be studied within anthropology or linguistics. ${ }^{8}$

Finally, the 'canon' of African political thought, as it might be constructed out of resources already available to many university teachers such as volumes by Idahosa (2004), Rabaka (2009) or Martin (2012), falls all too readily into writings published by 'great men' with little or no attention to the political contributions of African women. Whilst there are a few volumes that may expand the reading list, such as that by Mikell (1997), incorporating the political thought of African women - often activists - seems to more fundamentally disturb the theory-praxis binary upon which the idea of 'African political thought' is built. This calls into question one of the key principles on which the entire idea of the academy is built - the priority of the written word and performed theoretical analysis over the living speech or act as a means of intellectual advancement.

\footnotetext{
${ }^{8}$ One attempt to view African proverbs as a form of IR theory was discussed in a seminar at the LSE on 'The practice of ethnic diplomacy' run by Marta de Iňiguez de Heredia and funded by the BISA Africa and International Studies working group. See http://www.open.ac.uk/socialsciences/bisa-africa/events.shtml
} 
This is the Accepted Version of an article published online by Sage in Politics

Please refer to final version when citing, published online 1 May 2016 available at:

$\underline{10.1177 / 0263395716628886}$

Accepted Version downloaded from SOAS Research Online: http://eprints.soas.ac.uk/22523/

\section{Creativity in teaching Africa}

Another way to meet the challenges of teaching Africa and IS is to branch out into more creative approaches of teaching (hooks 1994). One of the most exciting and rewarding aspects which emerges from this forum is the diversity and creativity of texts, sources, materials and methods which colleagues draw upon. Feature films, online clips, novels, media articles, biographies and many more are used to stimulate and challenge student perceptions and representations of Africa. ${ }^{9}$ Routley, Gibert and Matthews all discuss how they integrate film and media reviews into teaching programmes, to "bring in more voices', to widen ways of assessing students and to foreground black African authors in the context of universities where staff remain overwhelmingly white. Many colleagues use novels to provide alternative perspectives on African politics in ways which are either central or supplementary to the academic study of the subject, and students often find their enthusiasm for Africa sparked by reading classics by Chinua Achebe or Ngũgĩ wa Thiong'o, or newer writers such as Chimamanda Ngozi Adichie or Binavanga Wainaina. There are also many far less conventional ways of drawing upon the creative arts in teaching Africa and IS, including sculpture, ceramics, paintings, music, theatre, poetry, cartoons and games.

Thinking more systematically about the possibilities and potential for more creative ways of teaching African and IS, it seems that there are least three main ways of thinking about the pedagogical purpose of such initiatives. The first is purely instrumental: students often appreciate the variety, and, as Gibert notes, find the use of novels and film (especially) as a good way to begin to engage with unfamiliar subject matter. Such media can be a 'hook', a way to catch the attention of students and keep them interested and entertained by the course.

\footnotetext{
${ }^{9}$ Many of these suggestions are now available on the BISA Africa and International Studies working group webpage. See http://www.open.ac.uk/socialsciences/bisa-africa/teachingafrica/course-outline-teaching-materials.php
} 
This is the Accepted Version of an article published online by Sage in Politics

Please refer to final version when citing, published online 1 May 2016 available at:

$\underline{10.1177 / 0263395716628886}$

Accepted Version downloaded from SOAS Research Online: http://eprints.soas.ac.uk/22523/

Teaching has a performative and aesthetic element which is sometimes neglected or denied by academic purists, and there is no need to apologise for using diverse sources to stimulate student engagement (hooks 1994: 11).

However, there are at least two further purposes for which such creative media can be used in the classroom. The first is to enable students to develop new skills of reading very different 'texts' - a film requires different modes of analysis to an academic article or textbook chapter, for example. These new ways of reading and understanding can be challenging in several ways, not only in terms of the skills required to conduct an academically-rigorous analysis of a painting, for example, but also in terms of challenging the types of knowledge, representation and discourse through which we normally understand Africa and the international. Thus the medium can become the message, and it is possible (although certainly not inevitable) that the use of African literature or art can challenge mainstream discourses of Eurocentric politics (see Cornelissen et al 2011; Shilliam 2011), achieving some of the destabilising of dominant narratives called for in Niang's chapter.

And third, the use of creative media and sources can involve the students more directly as active contributors to knowledge, rather than as the passive recipients of academic truths (Freire 2005). It is almost inevitable that in a context where the texts are academic articles and books, students are largely reliant on the lecturer and tutors as the creators and primary interpreters of these sources. But our classes contain many talented performers, artists, editors and authors, and more creative forms of teaching can begin to challenge some of the teacher-learner power relations which structure the classroom. The potential for challenging assumptions about who can produce knowledge about Africa and IS, and what form this knowledge takes, is one which educators and course designers should be prepared to tackle - even though it often means relinquishing their assumed position of authority (Giroux 1988). 
This is the Accepted Version of an article published online by Sage in Politics

Please refer to final version when citing, published online 1 May 2016 available at:

$\underline{10.1177 / 0263395716628886}$

Accepted Version downloaded from SOAS Research Online: http://eprints.soas.ac.uk/22523/

\section{Encouraging introspection in the classroom}

The discussion of creativity and diverse types of texts also opens up bigger political issues of power, representation and subjectivity. As Routley's article shows, 'foregrounding representational issues' can lead to encouraging introspection and prompting students to think about their relationship to Africa, Africans, and the global power relations which condition Africa's place in world politics. The articles in this forum all reflect to some degree on the types of students being taught, and the types of challenges these present. Almost inevitably, this also requires reflection upon the subject positions inhabited by the teachers: Matthews and Routley reflect most explicitly upon the politics of being white and teaching African politics; Niang considers what it might mean to provide an 'African outlook' within IR in a historically white African university; and Harris and Ambrozy show how the location of the classroom - in their case the Africa Studies Visit - can shape relationships between teachers and students, Africa and the world. As Freire argued, '[t]he teacher is no longer merely theone-who-teaches, but one who is himself [sic] taught in dialogue with the students, who in turn while being taught also teach' (2005: 80).

Death has argued 'that the particular context of the classroom, and various subject positions within that classroom, will have an important effect on the forms of learning and teaching achieved', and that the classroom offers a space to challenge both students and teachers to reflect upon their place in global power relations, discourses and political economies which often reproduce inequality and injustice (Death 2013: 78). Not everyone shares this view, however. Some argue that the classroom is one place in which to encourage students to try to view the world objectively, or from the perspective of a text's author. Different philosophies of teaching and learning, and different political outlooks, will therefore have a bearing on the degree to which our own subject positions and relationships become a focus of study. Certainly, it would be sad if one of the few opportunities to learn about and discuss Africa in mainstream IS programmes 
This is the Accepted Version of an article published online by Sage in Politics

Please refer to final version when citing, published online 1 May 2016 available at:

$\underline{10.1177 / 0263395716628886}$

Accepted Version downloaded from SOAS Research Online: http://eprints.soas.ac.uk/22523/

became simply another opportunity for European students to reflect upon their own place in the world.

That said, there are good reasons why some form of reflection and introspection should be considered within the classroom. One is simply that to try to ignore the context and politics in which we teach is naïve: education is both shaped by power relations and plays an important role in challenging and/or reproducing power relations (Müller, 2011). When it comes to race, for example, as Routley notes there is a shockingly low proportion of black professors in the UK academy, and Matthews reflects upon the over-representation of white students and staff in South African universities. Other relations of gender, class, language and religion also structure our classrooms, and it is better to recognise and discuss these than pretend they do not exist (Mama 2007).

Another reason is most vividly highlighted by Harris and Ambrozy's chapter on the Africa Study Visit, but it is a broader feature of all challenging higher education environments. Simply put, good education should challenge and unsettle students (and staff), and sometimes this can be profoundly disturbing. Harris and Ambrozy report on attempts to help students process the confusion and dislocation caused by the study visit through discussion groups or the palaver hut'. They note that in some cases this manifested as something of an 'existential crisis', and one student confided, 'I don't know what to think any more'. For some students, discussions of issues like colonialism, female genital mutilation, race and religion, African conflicts, migration and so on can become personally very disturbing and indeed traumatic. This is not a suggestion that such topics should be avoided, far from it. We should not aim to produce students who are 'well-adapted' to a world that is unjust, violent and unsustainable (Freire 2005: 76). But we do have a pedagogic responsibility to help students raise and deal with troubling issues in a supportive and safe environment. Treating all students as the same, and all classrooms as the same, is politically naïve and ultimately pedagogically irresponsible. 
This is the Accepted Version of an article published online by Sage in Politics

Please refer to final version when citing, published online 1 May 2016 available at:

$\underline{10.1177 / 0263395716628886}$

Accepted Version downloaded from SOAS Research Online: http://eprints.soas.ac.uk/22523/

\section{Conclusion: what kind of graduates are we trying to produce?}

African politics, and African contributions to thinking about and acting in the world, constitute an important and fascinating field of study. They are at once exceptional and mundane: they can challenge and provoke existing assumptions and approaches, present alternative outlooks; but they are also 'politics as usual', normal, because they belong to a significant proportion of the world's population.

Perhaps it is time to turn around the debate and explore the possibilities of what teaching Africa and IS, and IS in Africa, offer us as teachers of many thousands of the next generation of citizens. If our aim is simply to generate students who are familiar with the existing canon of IR knowledge, and who possess all the traits associated with traditional higher education, our role is limited. But if our aim is to produce students who will continue to question and challenge the existing world order, and actively participate in bringing about change, then we need to seriously rethink what we teach, and how we teach it.

\section{Bibliography}

Adichie, C.N. (2013) 'The Danger of Single Story'. TED talk. Available online at http://www.ted.com/talks/chimamanda_adichie_the_danger_of_a_single_story?l anguage $=$ en [accessed, 5 August 2015]

Aydinli, Ersel and Julie Matthews (2000) 'Are the Core and Periphery Irreconcilable? The Curious World of Publishing in International Relations International Studies Perspectives 1(3): 289-303 
This is the Accepted Version of an article published online by Sage in Politics

Please refer to final version when citing, published online 1 May 2016 available at:

$\underline{10.1177 / 0263395716628886}$

Accepted Version downloaded from SOAS Research Online: http://eprints.soas.ac.uk/22523/

Ayers, A. J. (2006). Beyond the Imperial Narrative: African Political

Historiography Revisited in B. G. Jones (ed.) Decolonizing international relations.

(Rowman \& Littlefield Publishers)

Bilgin, Pinar (2008) 'Thinking Past "Western" IR?', Third World Quarterly 29(1):

5-23

Brown, Will and Sophie Harman (eds) (2013) African Agency in International

Politics (London: Routledge)

Clapham, C. (1996) Africa and the International System: The Politics of State

Survival (Cambridge: Cambridge University Press.)

Cornelissen, Scarlett, Fantu Cheru and Timothy Shaw (2011) Africa and

International Relations in the 21st Century (Houndsmills, Basingstoke: Palgrave

Macmillan)

Death, Carl (2013) 'Postcolonial perspectives on teaching African politics in

Wales and Ireland', in Brandon D. Lundy and Solomon Negash (eds) Teaching

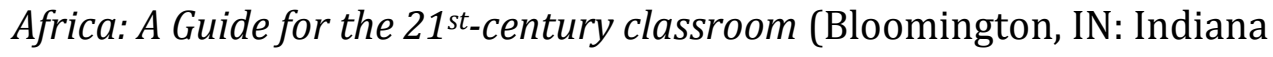

University Press)

Death, Carl et al (2015) 'Is there a "learning crisis" in Africa? Education and development post-2015', The Davies Papers: Africa Series, 8, available at http://www.aber.ac.uk/en/media/departmental/interpol/ddmi/thedaviesserie s/africaseries/19932-Africa-Series-8.pdf [accessed 5 August 2015]

Dunn, K. (1996). Lights...Camera...Africa: Images of Africa and Africans in Western Popular Films of the 1930s, African Studies Review, 39(01): 149-175

Dunn, K. and Shaw, T. (2001) Africa's Challenge to International Relations Theory (New York: Palgrave) 
This is the Accepted Version of an article published online by Sage in Politics

Please refer to final version when citing, published online 1 May 2016 available at:

$\underline{10.1177 / 0263395716628886}$

Accepted Version downloaded from SOAS Research Online: http://eprints.soas.ac.uk/22523/

Evans, M., \& Glenn, I. (2010). “"TIA-This is Africa”: Afropessimism in Twenty-

First-Century Narrative Film', Black Camera 2(1): 14-35

Fanon, Frantz (1986) Black Skin, White Masks, tr. C. L. Markmann, (London:

Pluto)

Freire, Paulo (2005) Pedagogy of the Oppressed, translated by Myra Bergman

Ramos, with an introduction by Donald Macedo (New York: Continuum)

Gallagher, Julia (2011) Britain and Africa under Blair: in pursuit of the good state (Manchester: Manchester University Press)

Giroux, Henry A. (1988) Teachers as Intellectuals: Toward a Critical Pedagogy of Learning (Westpoint: Bergin and Garvey)

Harrison, Graham (2013) The African Presence: representations of Africa in the construction of Britishness (Manchester: Manchester University Press)

bell hooks (1994) Teaching to Transgress: Education as the practice of freedom (New York: Routledge)

Idahosa, P. L. E. (2004) The populist dimension to African political thought: critical essays on reconstruction and retrieval (Africa World Press)

Jackson, R. H. (1993). Quasi-States: Sovereignty, International Relations and the Third World. (Cambridge: Cambridge University Press)

Keesing-Styles, L. (2003) 'The Relationship between Critical Pedagogy and Assessment in Teacher Education', Radical Pedagogy, 5(1). Online only: http://www.radicalpedagogy.org/radicalpedagogy/The Relationship between 
This is the Accepted Version of an article published online by Sage in Politics

Please refer to final version when citing, published online 1 May 2016 available at:

$\underline{10.1177 / 0263395716628886}$

Accepted Version downloaded from SOAS Research Online: http://eprints.soas.ac.uk/22523/

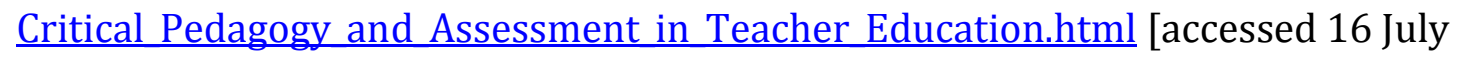
2015]

Lonsdale, John (2005) 'African Studies, Europe, and Africa', Afrika Spectrum, 40(3): 377-402

Mama, Amina (2007) 'Is it ethical to study Africa? Preliminary thoughts on scholarship and freedom', African Studies Review, 50(1): 1-26

Martin, G. (2012) African political thought (Palgrave Macmillan)

Mikell, G. (1997) African Feminism: The Politics of Survival in Sub-Saharan Africa (University of Pennsylvania Press)

Mudimbe, V. Y. (1990) The Invention of Africa: Gnosis, Philosophy and the Order of Knowledge (Bloomington: James Currey)

Müller, Martin (2011) 'Education and the formation of geopolitical subjects', International Political Sociology 5: 1-17

Nash, K. (2008) 'Global citizenship as show business: the cultural politics of Make Poverty History' Media, Culture \& Society 30(2): 167-181.

Nossal, Kim Richard (2001) 'Tales that Textbooks Tell: Ethocentricity and diversity in American introductions to International Relations' in Robert M. A. Crawford and Darryl S. L. Jarvis (eds) International Relations - Still a American Social Science? Towards Diversity in International Thought (Albany: States University of New York Press): 167-86

Pella Jr, J. A. (2014) Africa and the Expansion of International Society: Surrendering the Savannah (London: Routledge) 
This is the Accepted Version of an article published online by Sage in Politics

Please refer to final version when citing, published online 1 May 2016 available at:

$\underline{10.1177 / 0263395716628886}$

Accepted Version downloaded from SOAS Research Online: http://eprints.soas.ac.uk/22523/

Rabaka, R. (2009) Africana critical theory: reconstructing the black radical tradition, from W. E. B. Du Bois and C. L. R. James to Frantz Fanon and Amilcar Cabral (Lexington Books)

Sabaratnam, M. (2013) 'Africa and International Studies: From

Development/Security to African Political Thought', Presentation at 'Teaching Africa and International Studies I' workshop, University of Cambridge, 17 April 2013 (available online: http://www.open.ac.uk/socialsciences/bisaafrica/teaching-africa/course-outline-teaching-materials.php)

Said, E. W. (2003 [1978]) Orientalism (London: Penguin)

Shilliam Robbie (ed.) (2011) International Relations and Non-Western Thought: Imperialism, colonialism and investigations of global modernity (Abingdon: Routledge)

Theory Talks (2011) \#40 'Kenneth Neal Waltz: The Physiocrat of International Society': http://www.theory-talks.org/2011/06/theory-talk-40.html [accessed 16 July 2015] 